\title{
Relationship of dissolved inorganic carbon (DIC) concentrations with some environmental variables in the Red River water in the period 2008 - 2015
}

\author{
Mối quan hệ giũa hàm lương cacbon vô co dạng hòa tan (DIC) với một số \\ yếu tố môi trường trong nước sông Hồng trong giai đoạn 2008 - 2015 \\ Research article
}

Le, Thi Phuong Quynh ${ }^{1 *}$; Phung, Thi Xuan Binh ${ }^{2}$; Duong, Thi Thuy ${ }^{3}$; Le, Duc Nghia ${ }^{1}$; Ho, $\mathrm{Tu}$ Cuong ${ }^{3}$

${ }^{1}$ Institute of Natural Product Chemistry, Vietnam Academy of Science and Technology, 18 Hoang Quoc Viet, Cau Giay, Hanoi, Vietnam; ${ }^{2}$ Electric Power University, 235 Hoang Quoc Viet, Bac Tu Liem, Hanoi, Vietnam, ${ }^{3}$ Institute of Environmental Technology, Vietnam Academy of Science and Technology, 18 Hoang Quoc Viet, Cau Giay, Hanoi, Vietnam

\begin{abstract}
Dissolved Inorganic Carbon (DIC) is one of the main chemical components in water and very sensitive with environmental changes. DIC content in river water closely relates with natural weathering process and human activities in the whole basin. Therefore, DIC concentration reflects the impact of natural conditions and human activities in the basin to river water quality. This paper presents the survey results of the DIC concentrations at 4 sites in the Red River system during the period from January 2008 to December 2015 and simultaneously considers the relationship between some environmental variables and the DIC concentrations in the river water. The survey results showed that the DIC concentrations in the Red River water varied from 9.1 to $29.9 \mathrm{mgC} . \mathrm{L}^{-1}$, averaging 19.6 $\mathrm{mgC} . \mathrm{L}^{-1}$ during the study period. The DIC concentrations are positively correlated with $\mathrm{pH}$ values and some major ions concentrations in river water, such as $\mathrm{K}^{+}, \mathrm{Na}^{+}, \mathrm{Ca}^{2+}, \mathrm{SO}_{4}{ }^{2-}$ but negatively correlated with water temperature. These relationships also indicate that the DIC concentrations in the Red River water are influenced by natural conditions, rather than by human activities in the river basin.

Cacbon vô co hòa tan (DIC) là thành phần hóa học co bản trong nước và rất nhạy cảm với nhũng thay đổi của các yếu tố môi trường. DIC có mối liên hệ chặt chẽ với sự phong hóa tự nhiên và các hoạt động của con người trên quy mô toàn lưu vưc. Do đó, DIC phản ánh mức độ tác động của các điều kiện tụ nhiên và con nguời trong luu vưc tới chất lượng nước sông. Bài báo trình bày kết quả quan trắc hàm lự̛ng DIC trong nước sông Hồng, đồng thời xem xét mối quan hệ giữa một số yếu tố môi truờng với hàm luợng DIC trong nước sông trong giai đoạn 1/2008-4/2015. Kết quả cho thấy hàm lượng DIC trong nước sông Hồng dao động trong khoảng 9,1 to 29,9 mgC.L-1, trung bình đạt 19,6 mgC.L ${ }^{-1}$ trong giai đoạn tháng 1 năm 2008 - tháng 12 năm 2015. Hàm lương DIC có mối tuơng quan theo tỷ lệ nghịch với nhiệt độ nuớc sông; đồng thời có mối tuoong quan tỷ lệ thuận với giá trị pH và hàm luợng một số ion nhu $\mathrm{K}^{+}, \mathrm{Na}^{+}, \mathrm{Ca}^{2+}, \mathrm{SO}_{4}^{2-} \ldots$ tại 4 vị trí quan trắc trên sông Hồng. Các mối quan hệ này thể hiện rằng hàm luợng DIC trong nước sông Hồng chịu ảnh hương chính của các đặc điểm tụ nhiên hơn là các tác động của con nguời trong lưu vục.
\end{abstract}

Keywords: dissolved inorganic carbon (DIC), weathering, Red River 


\section{Introduction}

Dissolved inorganic carbon (DIC) is basic component of water and very sensitive with environmental factors, strongly influenced by rock weathering and human activities in the whole basin. The previous studies showed that DIC is the major component of the total carbon load of many rivers in the World such as the Mississippi, the St Lawence, the Nile River and the most of rivers in China. Some previous studies reported that the World rivers transport about $500-700 \times 10^{6}$ tonC.yr ${ }^{-1}$, of which about $45 \%$ is DIC [11]. Recently, the DIC load from the global river systems is estimated at $33-400 \times 10^{6}$ tonC. $^{-1} r^{-1}[3]$, [7], [9], [10].

The Red River is one of the largest river in Vietnam and is a good example of the South-East Asian river which is strongly impacted by both natural conditions and human activities in its basin. Like many other rivers in the world, the water quality of this river including inorganic carbon is influenced by both natural conditions and human activities. However, the researches about the carbon concentrations, especially DIC concentration of the Red River are still limited. This paper presents the observation results of the DIC concentration of the Red River during the period from January 2008 to December 2015. The relationship between some environmental variables and DIC concentrations in the Red River water are also considered in this paper.

\section{Methodology}

\subsection{Site study}

The Red River consists of three major tributaries, which are the Da, Lo and Thao Rivers, with a total area of about $156.450 \mathrm{~km}^{2}$. Throughout the whole river catchment, the average air temperature is $14-27^{\circ} \mathrm{C}$; the average humidity is $60-82 \%$ and the average annual rainfall is $1590 \mathrm{~mm}$. There are some big reservoirs in the Red River basin, which are utilized for multi-purposes such as flood control, agricultural irrigation, hydropower, water supply and flow management. The major reservoirs include: the Hoa Binh (water surface area of $218 \mathrm{~km}^{2}$, water volume: $9.5 \mathrm{~km}^{3}$ ) and the Son La (surface area is $440 \mathrm{~km}^{2}$, water volume: 25.5 $\mathrm{km}^{3}$ ) located on the Da River; and the Thac Ba (water surface area: $234 \mathrm{~km}^{2}$, water volume: $3.6 \mathrm{~km}^{3}$ ) located on the Chay river, the Tuyen Quang (surface area of $42 \mathrm{~km}^{2}$, water volume: $3 \mathrm{~km}^{3}$ ) on the Lo - Gam - Chay system [6].

The population density is not evenly distributed, the lowest is in the Da sub-basin and the highest is in the Delta region. In the whole basin area, the forest land and pastureland mainly dominate $34 \%$ and $24 \%$ respectively in the upstream part; the industrial crops accounted for $13 \%$, accounting for $8 \%$ of paddy land; and urban land represents only a very small part $(<1 \%)$.

\subsection{Method}

Sampling campaigns: Water samples were monthly taken during the period from January 2008 to April 2015 at four hydrological stations located in the Red River system, which are Yen Bai station (outlet of the Thao river), Hoa
Binh station (outlet of the Da river), Vu Quang station (outlet of the Lo river) and Hanoi station (downstream main axe of the Red River) (Figure 1).

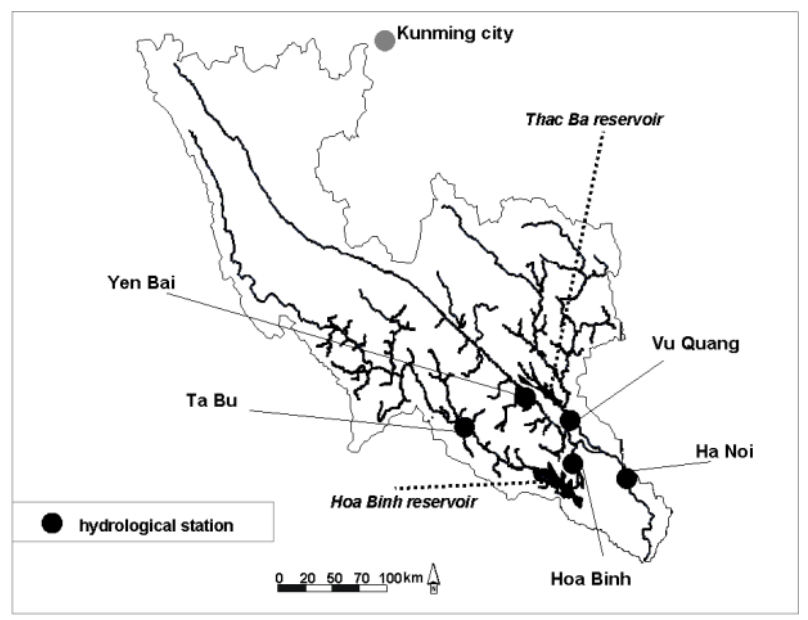

Figure 1: The Red River basin and hydrological stations

Analytical measurements: $\mathrm{pH}$ value was measured in-situ by a water quality checker WQC-22A (TOA, Japan). $\mathrm{HCO}_{3}{ }^{-}$content was determined by titration method with $0.01 \mathrm{M} \mathrm{HCl}$ within 12 hours after sampling (APHA, 1995). For each sample, three duplicates were titrated and the analytical error was below $3 \%$. Ions $\left(\mathrm{K}^{+}\right.$and $\left.\mathrm{Na}^{+}\right)$were determined by the atomic absorption spectroscopy method on the AAS 240FS (Varian, Australia). $\mathrm{SO}_{4}{ }^{2-}$ was spectrophotometrically measured by the APHA method (1995) on the UV-VIS V-630 (JASCO, Japan).

\section{Results and discussion}

\subsection{DIC concentrations of the Red River}

The $\mathrm{pH}$ values at all sampling sites were within 6.5 and 8.5. As known, if $\mathrm{pH}$ value of river water is lower than 6.3, almost carbonate ions in river water are converted to dissolved $\mathrm{CO}_{2}$; if $\mathrm{pH}$ is higher than 10.3 , almost carbonate ions are dominated by the $\mathrm{CO}_{3}{ }^{2-}$ ion; and if $6.3<\mathrm{pH}<10.3$, almost carbonate ions are mainly under $\mathrm{HCO}_{3}{ }^{-}$ion. Thus, with $\mathrm{pH}$ values of the Red River from 6.5 to 8.5 , DIC in Red River water over the years at all monitoring station will exist primarily in form of $\mathrm{HCO}_{3}{ }^{-}$.

During the period from 2008 - 2015, the DIC concentrations at four gauging stations were in the range of $9.1-$ $29.9 \mathrm{mgC} . \mathrm{L}^{-1}$, with an average value of $19.6 \mathrm{mgC} . \mathrm{L}^{-1}$ for the whole river system. It was observed that the mean value of the DIC concentration at $\mathrm{Vu}$ Quang station was the highest $\left(22.1 \mathrm{mgC.L} \mathrm{L}^{-1}\right)$, followed by Hanoi station (20.0 mgC.L $\mathrm{L}^{-1}$ ), Yen Bai station (18.7 mgC.L $\mathrm{m}^{-1}$ ) and Hoa Binh station $\left(17.7 \mathrm{mgC}^{-1}\right)$. There was no clear difference for the mean DIC concentrations within four stations during the monitoring years (Figure 2). 
Table 1: Mean DIC concentrations at monitoring stations during the period 2008-2015

\begin{tabular}{|c|r|r|r|r|}
\hline Year & $\begin{array}{c}\text { Yen } \\
\text { Bai }\end{array}$ & Hoa Binh & Vu Quang & Ha Noi \\
\hline 2008 & 19.8 & 18.7 & 21.8 & 20.5 \\
\hline 2009 & 18.5 & 15.3 & 19.7 & 19.3 \\
\hline 2010 & 18.5 & 15.2 & 20.9 & 19.1 \\
\hline 2011 & 15.5 & 18.7 & 20.9 & 18.9 \\
\hline 2012 & 17.0 & 14.9 & 21.8 & 19.7 \\
\hline 2013 & 17.3 & 16.9 & 22.9 & 19.3 \\
\hline 2014 & 19.2 & 19.7 & 22.6 & 19.5 \\
\hline 2015 & 23.6 & 22.0 & 26.2 & 24.0 \\
\hline Average & $\mathbf{1 8 . 7}$ & $\mathbf{1 7 . 7}$ & $\mathbf{2 2 . 1}$ & $\mathbf{2 0 . 0}$ \\
\hline
\end{tabular}

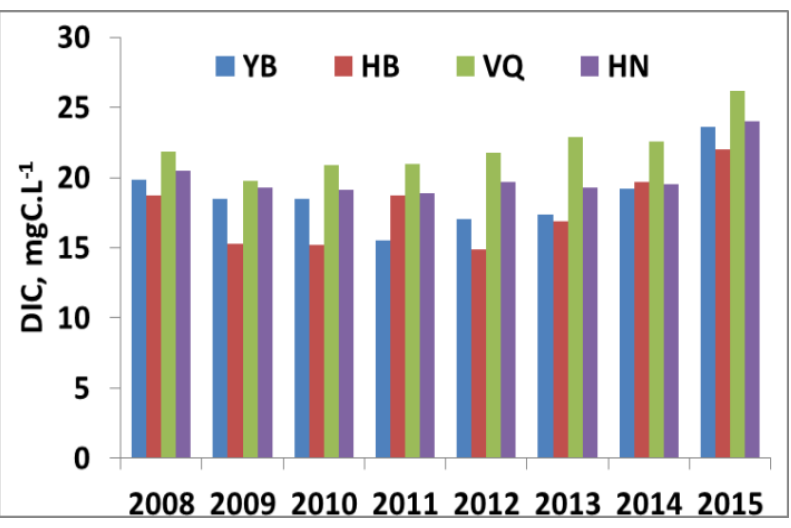

Figure 2: Mean DIC concentrations at four monitoring stations during the period 2008-2015

The mean value of the DIC concentration of the Red River was closed with the ones from some rivers in tropical regions such as the the Yangtze River (in Asia) (28mgC.L $\mathrm{L}^{-1}$ ) [3], the Ganga/Bramaputra River $\left(23 \mathrm{mgC}^{-1} \mathrm{~L}^{-1}\right)$ [15], the Irrawaddy River (24 $\left.\mathrm{mgC} . \mathrm{L}^{-1}\right)$ [2], the Zhujiang River: 20 mgC.L ${ }^{-1}$ [19], the Jinshajiang River: $27.6{\mathrm{mgC} . \mathrm{L}^{-1}}_{\text {[4], the }}$ Han River: 29.6 mgC.L ${ }^{-1}$ [8], but much lower than the ones of the Tuotuo River: $55.4 \mathrm{mgC} . \mathrm{L}^{-1}$, the Tongtian River: $58.8 \mathrm{mgC} . \mathrm{L}^{-1}[12]$ However, this value was higher than the ones of some other World Rivers such as the Amazon: 4 mgC.L ${ }^{-1}$ [13], the Zaire: $3{\mathrm{mC} . \mathrm{L}^{-1}}_{\text {[5], the Susque- }}$ hanna/Hudson River: $3.8 \mathrm{mgC} . \mathrm{L}^{-1}$, the York River 6.7 mgC.L ${ }^{-1}$; the Parker River: $9.9{\mathrm{mgC} . \mathrm{L}^{-1}}^{\text {[14] }}$ and especially, higher than the mean value of the world rivers: 9.6 mgC.L ${ }^{-1}$ [17]. According to Cai et al (2008) [3], the different DIC concentrations in rivers may not depend only on the percentage of carbonate rocks distributing in their drainage basins and that the very high DIC concentrations in rivers due to the fact that they have a much higher evaporation water loss over precipitation rate in a large part of their river basins (i.e., low water river discharge).

\subsection{Relationship between DIC concentrations and some environmental variables in the Red River water}

\section{Relationship with water temperature}

The increase of river water temperature may provide favourable conditions for the ion dissociation in water, and accelerate chemical reactions in water. When the water temperature rises, the solubility of $\mathrm{CO}_{2}$ in water decreases, then the ability of $\mathrm{H}_{2} \mathrm{CO}_{3}$ forming in water decreases, thus $\mathrm{H}^{+}$will be less, and $\mathrm{pH}$ increases, and DIC concentration decreases. Figure 3 shows an inversely proportional correlation between the river water temperature and DIC concentration at all monitoring stations of the Red River system.
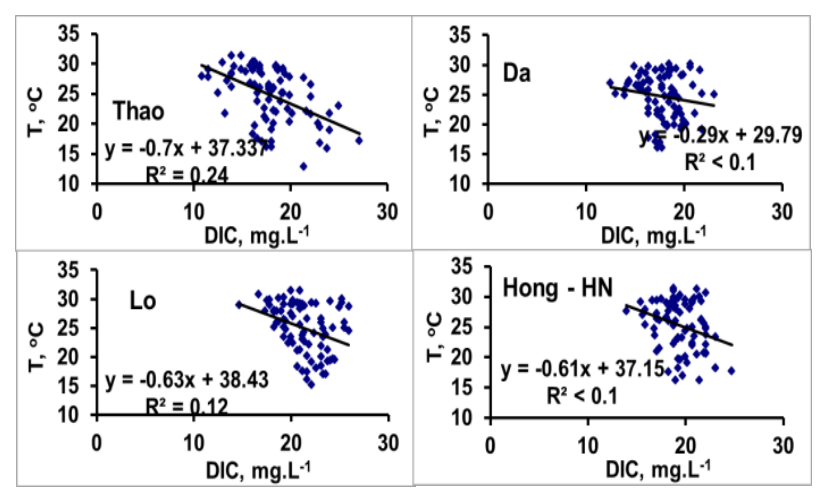

Figure 3: Relationship between DIC and water temperature of the Red River water at four stations

\section{Relationship with pH}

The concentration of ion $\mathrm{H}^{+}$is not only dependent on the dissociation of water but also on the separation of ions $\mathrm{CO}_{3}{ }^{2-}, \mathrm{HCO}_{3}{ }^{-}, \mathrm{CO}_{2}$. Typically, ion $\mathrm{H}^{+}$concentration depends mainly on the concentration of bicarbonate ions $\left[\mathrm{HCO}_{3}-\right]$ basing on an inversely proportional relationship. That means, when $\mathrm{HCO}_{3}{ }^{-}$concentration increases $\mathrm{H}^{+}$concentration is reduced, thus, $\mathrm{pH}$ of the water will increase, and vice versa. The same trend between $\mathrm{pH}$ and bicarbonate ions $\left[\mathrm{HCO}_{3}{ }^{-}\right]$(i.e. DIC) was observed for the Red River water (Figure 4).
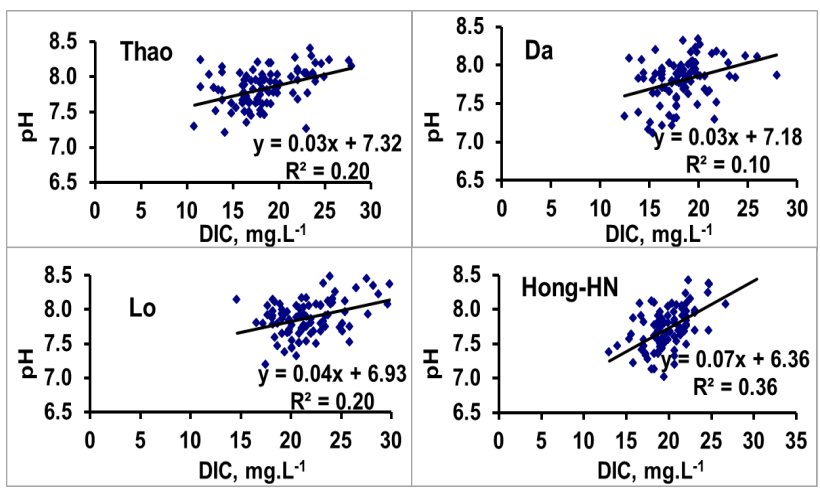

Figure 4: Relationship between DIC and pH in the Red River water at four sites

\section{Relationship with other ions}

a) Relationship with $\mathrm{K}^{+}$and $\mathrm{Na}^{+}: \mathrm{K}$ and $\mathrm{Na}$ are two elements which are supplied by natural rocks or by fertilizer applications in agriculture which is the main economic activity in the Red river drainage basin [12]. A positive correlation between $\mathrm{K}^{+}$and DIC concentration was observed for the Red River although it was not significant (Figure 5). 

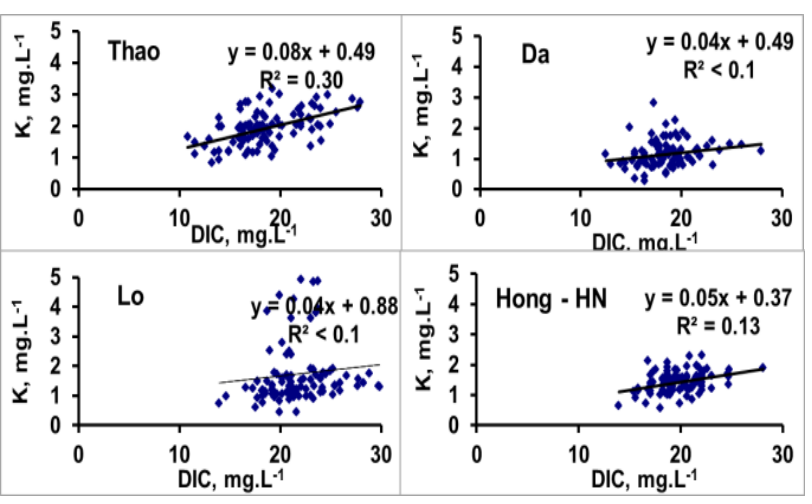

Figure 5: Relationship between DIC and $\mathrm{K}^{+}$in river water at four monitoring stations

A positive correlation between $\mathrm{Na}^{+}$concentration and DIC was also observed for all monitoring sites. (Figure 6).
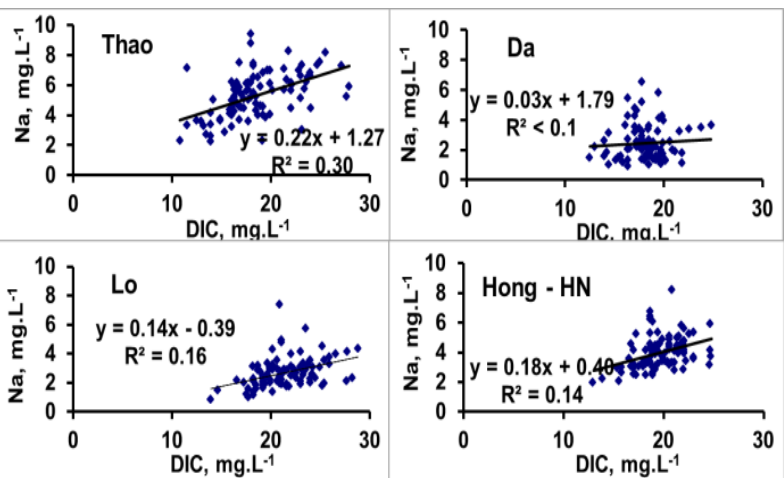

Figure 6: Relationship between DIC and $\mathrm{Na}^{+}$in river water at four monitoring stations

b) Relationship with $\mathrm{Ca}^{2+}$ :
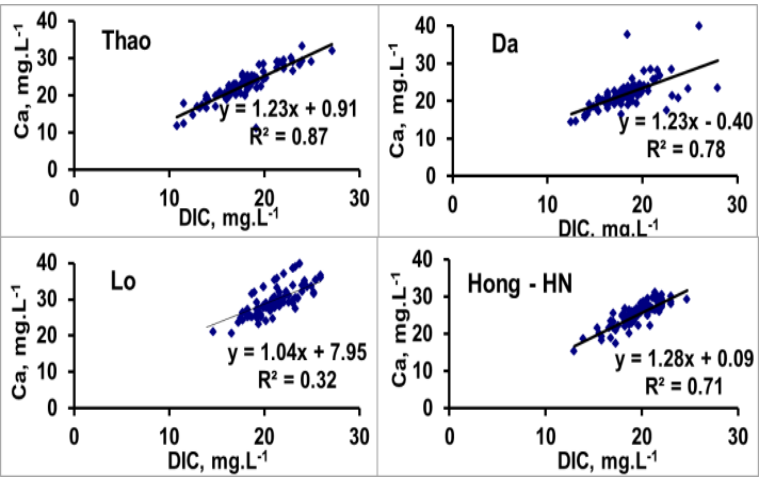

Figure 7: Relationship between DIC and $\mathrm{Ca}^{2+}$ in riverwater at four monitoring stations

$\mathrm{Ca}^{2+}$ concentrations showed a clear positive correlation with DIC concentrations at all four sites. This can be explained by chemical weathering of carbonate rocks in the basin, leading to the formation of $\mathrm{Ca}\left(\mathrm{HCO}_{3}\right)_{2}$ in river water and then $\mathrm{Ca}\left(\mathrm{HCO}_{3}\right)_{2}$ easily decompose into $\mathrm{Ca}^{2+}$ and $\mathrm{HCO}_{3}{ }^{-}$. Thus, the concentrations of $\mathrm{Ca}^{2+}$ and $\mathrm{HCO}_{3}{ }^{-}$will increase together.

d) Relationship with $\mathrm{SO}_{4}{ }^{2-}$ :
As known, $\mathrm{SO}_{4}{ }^{2-}$ concentration in the river water is supplied by natural conditions (dissolution of gypsum, oxidation of pyrite, volcanism, etc.) or by human activities in the river basin. In river water, the process of sulfate reduction were performed by microorganisms in anoxic environments and rich in organic matters. This process creates $\mathrm{H}_{2} \mathrm{~S}$ gas and simultaneously releases $\mathrm{HCO}_{3}{ }^{-}, \mathrm{CO}_{2}$, according to the following equation:

$$
2 \mathrm{SO}_{4}{ }^{2-}+4 \mathrm{C}+3 \mathrm{H}_{2} \mathrm{O} \rightarrow \mathrm{H}_{2} \mathrm{~S}+\mathrm{HS}^{-}+\mathrm{CO}_{2}+3 \mathrm{HCO}_{3}^{-}
$$
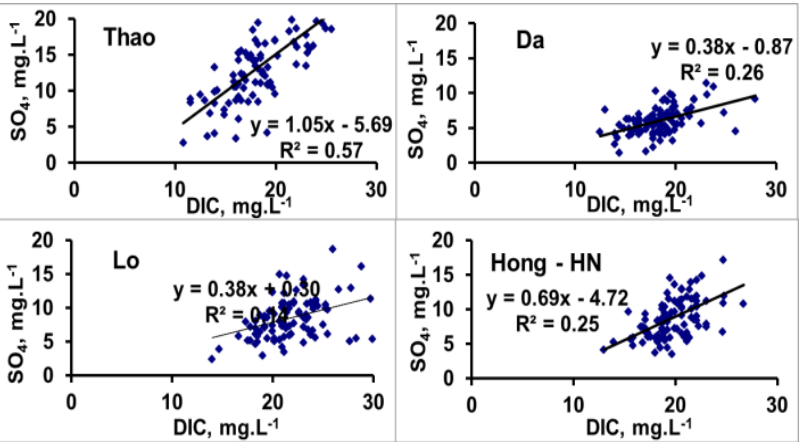

Figure 7: Relationship between DIC and $\mathrm{SO}_{4}{ }^{2-}$ in the Red River water

This proves that if more $\mathrm{SO}_{4}{ }^{2-}$ supplied in the river water, $\mathrm{HCO}_{3}^{-}$(DIC) concentration in the water will be also increased. $\mathrm{SO}_{4}{ }^{2-}$ concentrations tend to increase with DIC in the Red River water at all monitoring sites (Figure 7). This relationship is clearly observed at the Yen Bai station (Thao River) $\left(\mathrm{R}^{2}=0.57\right)$. Previous study [12] suggested that pyrite oxidation was the dominant source of sulfate in the upstream of the Red River basin as the distribution of coal-bearing and sulfide bearing deposits in this area.

\section{Conclusions}

The monitoring results at four sites in the Red River system during the period from 2008 - 2015 showed that the DIC concentrations were in the range of $9.1-29.9 \mathrm{mgC}^{-1} \mathrm{~L}^{-1}$ with an average value of $19.6 \mathrm{mgC} . \mathrm{L}^{-1}$ for the whole river system. There was no clear different for the mean DIC concentrations within four stations during the monitoring years.

The DIC concentrations in the Red River water have a positive correlation with the $\mathrm{pH}$ and some ions like $\mathrm{K}^{+}, \mathrm{Na}^{+}$, $\mathrm{Ca}^{2+}$ and $\mathrm{SO}_{4}{ }^{2-}$ but it showed a negative correlation with river water temperature. These relationships also indicate that the DIC concentrations in the Red River water are influenced by natural conditions, rather than by human activities in the river basin.

\section{Acknowledgements}

The authors would like to thank the Vietnam's National Foundation for Science and Technology Development (NAFOSTED-Vietnam) (105.09-2012.10 project) and Asia-Pacific Network for Global Change Research (ARCP2014_03CMY_Quynh project) and the IFS W/4674-2 for their financial supports. 


\section{References}

[1] APHA, AWWA and WEF, 1995. Standard methods for the examination of water and wastewater, $18^{\text {th }}$ edition, Washington DC., USA.

[2] Bird, M.I., Robinson, R.A.J., Win Oo N., Maung A.M., Lu X.X., Higgitt D.L., Swe A., Tun T., Lhaing Win S., Sandar Aye K., Mi Mi Win K., Hoey T.B. (2008) A preliminary estimate of organic carbon transport by the Ayeyarwady (Irrawaddy) and Thanlwin (Salween) Rivers of Myanmar. Quaternary International 186, 113-122.

[3] Cai W.J., Guo X., Chen C. T. A., Dai M., Zhang L., Zhai W., Lohrenz S., Yin K., Harrison P., Wang Y. (2008). A comparative overview of weathering intensity and $\mathrm{HCO}_{3}{ }^{-}$flux in the world's major rivers with emphasis on the Changjiang, Huanghe, Zhujiang (Pearl) and Mississippi Rivers, Continental Shelf Research, 28, 1538-1549.

[4] Chetelat, B., Liu, C., Zhao, Z., Wang, Q., Li, S., Li, J., Wang, B. (2008). Geochemistry of the dissolved load of the Changjiang Basin rivers: anthropogenic impacts and chemical weathering. Geochim. Cosmochim. Acta 72, 4254-4277.

[5] Coynel, A., Seyler, P., Etcheber, H., Meybeck, M., Orange, D. (2005b) Spatial and seasonal dynamics of total suspended sediment and organic carbon species in the Congo River. Global Biogeochemical Cycles 19, GB4019, doi:10.1029/2004GB002335.

[6] Le T.P.Q., Billen G., Garnier J., Thery S., Chau V.M. (2014). Long-term biogeochemical functioning of the Red River (Vietnam): past and present situations, Regional Environmental Change, 15, 329-339.

[7] Lerman, A., Wu, L., Mackenzie, F.T. (2007). $\mathrm{CO}_{2}$ and $\mathrm{H}_{2} \mathrm{SO}_{4}$ consumption in weathering and material transport to the ocean, and their role in the global carbon balance. Marine Chemistry, 106, 326 - 350.

[8] Li, S.Y., Xu, Z.F., Wang, H., Wang, J.H., Zhang, Q.F. (2009). Geochemistry of the upper Han River basin, China. 3: Anthropogenic inputs and chemical weathering to the dissolved load. Chem. Geol. 264, 89-95.

[9] Ludwig W, Amiotte Suchet P, Munhoven G, Probst JL. (1998). Atmospheric $\mathrm{CO}_{2}$ consumption by contiental erosion: present - day controls and implications for the last glacial maximum. Global Planet
Change, 17:107 - 120 .

[10] Mackenzie FT., Lerman, A., Andersson, A.J. (2004). Past and present of sidement and carbon biogeochemical cycling models. Biogeosciences 1, 11 -32.

[11] Meybeck M. (1993). Riverine transport of atmospheric carbon: source, global topology and budget. Water, Air and Soil Pollution 70 (1-4), 443 -463.

[12] Moon S., Huh Y, Qin J., Nguyen V.P. (2007). Chemical weathering in the Hong (Red) River basin: rates of silicate weathering and their controlling factors. Geochimica et Cosmochimica Acta 71 1411-1430

[13] Prosbt, J.L., Mortatti, J., Tardy, Y. (1994). Carbon river fluxes and weathering $\mathrm{CO} 2$ consumption in the Congo and Amazon river basins. App. Geochem. 9, $1-13$.

[14] Raymond PA, Bauer J.E., Caraco N.F., Cole J.J., Longworth B., Petsch S.T. (2004) Controls on the variability of organic matter and dissolved inorganic carbon ages in northeast US rivers. Marine Chemistry $92353-366$.

[15] Singh Singh, S.K., Sarin, M.M., France-Lanord, C. (2005) Chemical erosion in the eastern Himalaya: Major ion composition of the Brahmaputra and 13 of dissolved inorganic carbon. Geochimica et Cosmochemica Acta, 69, 3573-3588.

[16] Sun H.G., Han J., Lu X.X., Zhang S.R., Li D. (2010). An assessment of the riverine carbon flux of the $\mathrm{Xi}$ jiang River during the past 50 years, Quaternary International, 226, 38-43.

[17] Telmer, K., Veizer. J. (1999). Carbon fluxes, $\mathrm{PCO}_{2}$ and substrate weathering in a large northern river basin, Canada: Carbon isotope perspectives. Chem. Geol. 159. $61-86$.

[18] Wu, W., Yang, J., Xu, S., Yin, H. (2008b) Geochemistry of the headwaters of the Yangtze River, Tongtian $\mathrm{He}$ and Jinsha Jiang: silicate weathering and $\mathrm{CO}_{2}$ consumption. Appl. Geochem. 23, 3712-372.

[19] Zhang S, X.X. Lu, H. Sun, J. Han, D. L. Higgitt. (2009) Major ion chemistry and dissolved inorganic carbon cycling in a human - disturbed mountainous river (the Luodingjiang River) of the Zhujiang (Pearl River), China. Science of the Total Environment 407, $2796-2807$. 